\title{
EDITORIAL
}

\section{Co-infection in severe influenza: a new epidemiology?}

\author{
Charles-Edouard Luyt ${ }^{1,2^{*}}$ (D) and Todd W. Rice ${ }^{3}$
}

(C) 2016 Springer-Verlag Berlin Heidelberg and ESICM

In 2009, a novel influenza A (H1N1) virus emerged in Mexico and caused human infection, including severe pneumonia in young and previously healthy adults [1]. Since 2009, the virus has continued to circulate, causing cases of viral pneumonia and acute respiratory distress syndrome requiring intensive care unit (ICU) admission. Other serotypes [influenza B, A (H3N2)] circulate concomitantly and are also responsible for cases of severe acute illness requiring ICU admission [2]. Although primary viral pneumonia may evolve towards acute respiratory distress syndrome and death, bacterial co-infection is frequently described in these cases, may contribute to the development of ARDS and respiratory failure, and is clearly associated with higher mortality $[1,3]$.

In a study described in a recent article in Intensive Care Medicine, Martin-Loeches at al., investigated 2901 patients with influenza infection hospitalized in 148 Spanish ICUs from 2009 to 2015 and found that $16.6 \%$ of them had microbiologically confirmed community-acquired co-infection (i.e., co-infection diagnosed within the first 2 days of hospital admission) [4]. Similar to previously reported data from this group [5], Streptococcus pneumoniae was the predominant pathogen recovered, followed by Pseudomonas aeruginosa and methicillin-susceptible Staphylococcus aureus (MSSA). Not unexpectedly, data from the USA found that $S$. aureus was the predominant organism, with a higher prevalence of methicillin-resistant S. aureus (MRSA) [6]. Interestingly, the authors found an apparent increased rate of co-infection over time (from $11.4 \%$ in 2009 to $23.4 \%$ in 2015 ), without clear explanation. A recent meta-analysis showed that co-infection rates ranged from 2 to $65 \%$ [7]. This difference between

\footnotetext{
*Correspondence: charles-edouard.luyt@psl.ap-hop-paris.fr

1 Service de Réanimation Médicale, Groupe Hospitalier La Pitié-

Salpêtrière, Assistance Publique-Hôpitaux de Paris, Paris, France

Full author information is available at the end of the article
}

studies could be explained by differences in methods of sampling, timing of samples, prehospital antibiotic administration, and different definitions of co-infection (i.e., whether or not it was microbiologically confirmed, etc.). In the study by Martin-Loeches at al., it is difficult to draw conclusions on the exact incidence of co-infection and its increase over time: firstly, the definition of coinfection required laboratory confirmation and the study did not record the proportion of patients having received antimicrobials before hospital admission (which would decrease the ability to confirm co-infection in the laboratory and can vary over time); and secondly, as a result of the use of non-invasive techniques, namely tracheal aspirate, for diagnosing pneumonia, the authors might have missed some cases that would only be laboratory confirmed by more invasive sampling (i.e., bronchoscopy). Furthermore, they could have classified patients as having co-infection whereas they were only colonized [8]. This potential overestimation could also explain the high rate of $P$. aeruginosa co-infection observed in that study (14.1\%): in another recent study in patients with influenza-related infection, the authors found a $1.3 \%$ rate of $P$. aeruginosa co-infection in patients with CAP and $8.3 \%$ in patients with healthcare-associated pneumonia (HCAP) [9]. The high incidence found in the present study cannot be explained by a local (national) feature, since same authors reported lower rates of $P$. aeruginosa CAP and HCAP in Spain during this same time [10,11]. Either false positives (patients diagnosed as pneumonia whereas only colonized) or a specific, not yet described, influenza- $P$. aeruginosa co-infection (Shah at al., found similar incidence of $P$. aeruginosa [12]) could explain such high rates of $P$. aeruginosa pneumonia, especially if they truly are community acquired. The high rate of co-infection due to Aspergillus (7.2\%) is also surprising: although invasive pulmonary aspergillosis has been described in patients with H1N1-related pneumonia, it has rarely been

\section{Springer}


described as a community-acquired co-infection but more as a secondary fungal infection, even in immunosuppressed patients $[13,14]$. Although this study focused on community-acquired co-infection (and in fact excluded patients admitted from nursing homes or other healthcare facilities), the high incidences of $P$. aeruginosa and Aspergillus as pathogens responsible for co-infection is in favor of a mix of community-acquired infections and secondary bacterial and fungal infections.

Another surprising result of this paper is the absence of association between appropriate use of antibiotics and mortality, since this has been demonstrated years ago [15]. However, this could be explained not (only) by an unknown and complex host-pathogen interaction, as stated by the authors, but by the high reported rate of inappropriate empiric therapy $(>15 \%)$ that was similar in survivors and non-survivors [4]. The particular epidemiology of pathogens responsible for co-infection, specifically the higher than expected rates of $P$. aeruginosa and Aspergillus, may explain this finding.

Some important messages should be taken from this paper, as the winter is near in the northern hemisphere and we will soon probably face new cases of influenzarelated illness requiring ICU admission. First, co-infection is frequent in patients with influenza infection. Physicians taking care of these patients should strongly consider whether their critically ill influenza patient may be co-infected, and empirically treat with antibiotics. Second, co-infection is associated with higher mortality rate than primary viral infection. Although this was previously demonstrated in several studies, this is the largest study published to date that confirms this association. Rice at al., found, in 2012, that among 683 patients with influenza A H1N1 infection, bacterial co-infection was frequent (30.3\%) and associated with higher mortality rate as compared to patients without [6]. In a more recent study on 507 ICU patients, Shah at al., found a $22.5 \%$ rate of bacterial co-infection and a similar association between bacterial co-infection and death [12]. It is highly probable that the mechanism explaining the higher mortality is due to either to the bacterial infection itself or to an association of virulence factors from both virus and bacteria. Lastly, as shown in this paper and others, the epidemiology of pathogens responsible for co-infection is regional and likely depends on many local factors, but may also be subject to change over time, with emergence in the community of pathogens usually seen in nosocomial infections $[6,7,9,12]$.

These and previous data on co-infection rates and association with higher mortality beg the question of whether every patient with severe influenza should be treated with antibiotics? Unfortunately this paper does not give the answer to this crucial question, but the answer may very well be an emphatic "Yes". Given the high probability of bacterial co-infection in these patients, its association with mortality, and the fact that delaying antimicrobial treatment could be associated with even higher mortality [16], the empiric use of antimicrobial treatment in such patients should be encouraged. Although some biomarkers (and in particular procalcitonin) have been shown to be associated with bacterial co-infection in this setting, their accuracy is not sufficient to determine initiation of antimicrobial treatment [17]. Procalcitonin may be helpful in this setting as a marker to stop antimicrobial treatment in patients without proven infection and/or low procalcitonin level [18].

In summary, clinicians should keep in mind that coinfection is frequent in patients with influenza-related infection requiring ICU admission. Thus, empiric antimicrobial treatment should be started early. The choice of the initial antimicrobial treatment should be based on the local and national epidemiology and target pathogens responsible for CAP: in France and northern Europe, S. pneumoniae and methicillin-susceptible $S$. aureus seem to be the predominant pathogens. In the USA, the high incidence of methicillin-resistant $S$. aureus should be taken into account for the initial choice of antibiotics [6]. If $P$. aeruginosa incidence is increasing over time (which remains to be confirmed in further studies), it may also need empiric antimicrobial coverage since it may have an impact on overall mortality.

\section{Author details \\ ${ }^{1}$ Service de Réanimation Médicale, Groupe Hospitalier La Pitié-Salpêtrière, Assistance Publique-Hôpitaux de Paris, Paris, France. ${ }^{2}$ Sorbonne Universités, UPMC Université Paris 06, INSERM, UMRS_1166-ICAN Institute of Cardiometab- olism and Nutrition, Paris, France. ${ }^{3}$ Division of Allergy, Pulmonary, and Critical Care Medicine, Vanderbilt University School of Medicine, Nashville, TN, USA.}

Received: 11 October 2016 Accepted: 13 October 2016 Published online: 31 October 2016

References

1. Bautista E, Chotpitayasunondh T, Gao Z, Harper SA, Shaw M, Uyeki TM, Zaki SR, Hayden FG, Hui DS, Kettner JD, Kumar A, Lim M, Shindo N, Penn C, Nicholson KG (2010) Clinical aspects of pandemic 2009 influenza A (H1N1) virus infection. N Engl J Med 362:1708-1719

2. Loubet $P$, Samih-Lenzi N, Galtier F, Vanhems P, Loulergue P, Duval X, Jouneau S, Postil D, Rogez S, Valette M, Merle C, Regis C, Costa Y, Lesieur Z, Tattevin P, Lina B, Carrat F, Launay O (2016) Factors associated with poor outcomes among adults hospitalized for influenza in France: a three-year prospective multicenter study. J Clin Virol 79:68-73

3. Mauad T, Hajjar LA, Callegari GD, da Silva LF, Schout D, Galas FR, Alves VA, Malheiros DM, Auler JO Jr, Ferreira AF, Borsato MR, Bezerra SM, Gutierrez PS, Caldini ET, Pasqualucci CA, Dolhnikoff M, Saldiva PH (2010) Lung pathology in fatal novel human influenza A (H1N1) infection. Am J Respir Crit Care Med 181:72-79

4. Martin-Loeches I, Schultz M, Voincent JL, Alvarez-Lerma F, Bos LD, SoléViolan J, Torres A, Rodriguez A (2016) Increased incidence of co-infection 
in critically ill patients with influenza. Intensive Care Med. doi:10.1007/ s00134-016-4578-y

5. Martin-Loeches I, Sanchez-Corral A, Diaz E, Granada RM, Zaragoza R, Villavicencio C, Albaya A, Cerda E, Catalan RM, Luque P, Paredes A, Navarrete I, Rello J, Rodriguez A (2011) Community-acquired respiratory coinfection in critically ill patients with pandemic 2009 influenza A(H1N1) virus. Chest 139:555-562

6. Rice TW, Rubinson L, Uyeki TM, Vaughn FL, John BB, Miller RR 3rd, Higgs E, Randolph AG, Smoot BE, Thompson BT (2012) Critical illness from 2009 pandemic influenza A virus and bacterial coinfection in the United States. Crit Care Med 40:1487-1498

7. Klein EY, Monteforte B, Gupta A, Jiang W, May L, Hsieh YH, Dugas A (2016) The frequency of influenza and bacterial coinfection: a systematic review and meta-analysis. Influenza Other Respir Viruses 10:394-403

8. Chastre J, Luyt CE (2016) Does this patient have VAP? Intensive Care Med 42:1159-1163

9. Maruyama T, Fujisawa T, Suga S, Nakamura H, Nagao M, Taniguchi K, Tsutsui K, Ihara T, Niederman MS (2016) Outcomes and prognostic features of patients with influenza requiring hospitalization and receiving early antiviral therapy: a prospective multicenter cohort study. Chest 149:526-534

10. Valles J, Martin-Loeches I, Torres A, Diaz E, Seijas I, Lopez MJ, Garro P, Castillo C, Garnacho-Montero J, Martin Mdel M, de la Torre MV, Olaechea P, Cilloniz C, Almirall J, Garcia F, Jimenez R, Seoane E, Soriano C, Mesalles E, Posada P (2014) Epidemiology, antibiotic therapy and clinical outcomes of healthcare-associated pneumonia in critically ill patients: a Spanish cohort study. Intensive Care Med 40:572-581

11. Valles J, Diaz E, Martin-Loeches I, Bacelar N, Saludes P, Lema J, Gallego M, Fontanals D, Artigas A (2016) Evolution over a 15-year period of the clinical characteristics and outcomes of critically ill patients with severe community-acquired pneumonia. Med Intensiva 40:238-245

12. Shah NS, Greenberg JA, McNulty MC, Gregg KS, Jt Riddell, Mangino JE, Weber DM, Hebert CL, Marzec NS, Barron MA, Chaparro-Rojas F, Restrepo A, Hemmige V, Prasidthrathsint K, Cobb S, Herwaldt L, Raabe V, Cannavino
CR, Hines AG, Bares SH, Antiporta PB, Scardina T, Patel U, Reid G, Mohazabnia P, Kachhdiya S, Le BM, Park CJ, Ostrowsky B, Robicsek A, Smith BA, Schied J, Bhatti MM, Mayer S, Sikka M, Murphy-Aguilu I, Patwari P, Abeles SR, Torriani FJ, Abbas Z, Toya S, Doktor K, Chakrabarti A, Doblecki-Lewis S, Looney DJ, David MZ (2016) Bacterial and viral co-infections complicating severe influenza: incidence and impact among 507 U.S. patients, 2013-14. J Clin Virol 80:12-19

13. Guervilly C, Roch A, Ranque S, Forel JM, Hraiech S, Xeridat F, Adda M, Papazian L (2012) A strategy based on galactomannan antigen detection and PCR for invasive pulmonary aspergillosis following influenza $A$ (H1N1) pneumonia. J Infect 65:470-473

14. Alshabani K, Haq A, Miyakawa R, Palla M, Soubani AO (2015) Invasive pulmonary aspergillosis in patients with influenza infection: report of two cases and systematic review of the literature. Expert Rev Respir Med 9:89-96

15. Kollef MH, Sherman G, Ward S, Fraser VJ (1999) Inadequate antimicrobial treatment of infections: a risk factor for hospital mortality among critically ill patients. Chest 115:462-474

16. Dellinger RP, Levy MM, Rhodes A, Annane D, Gerlach H, Opal SM, Sevransky JE, Sprung CL, Douglas IS, Jaeschke R, Osborn TM, Nunnally ME, Townsend SR, Reinhart K, Kleinpell RM, Angus DC, Deutschman CS, Machado FR, Rubenfeld GD, Webb S, Beale RJ, Vincent JL, Moreno R (2013) Surviving Sepsis Campaign: international guidelines for management of severe sepsis and septic shock, 2012. Intensive Care Med 39:165-228

17. Pfister R, Kochanek M, Leygeber T, Brun-Buisson C, Cuquemelle E, Machado MB, Piacentini E, Hammond NE, Ingram PR, Michels G (2014) Procalcitonin for diagnosis of bacterial pneumonia in critically ill patients during 2009 H1N1 influenza pandemic: a prospective cohort study, systematic review and individual patient data meta-analysis. Crit Care 18:R44

18. Luyt CE, Brechot N, Trouillet JL, Chastre J (2014) Antibiotic stewardship in the intensive care unit. Crit Care 18:480 